\title{
Endless world of Blaise Pascal : a working bibliography.
}

\author{
Camille Akmut
}

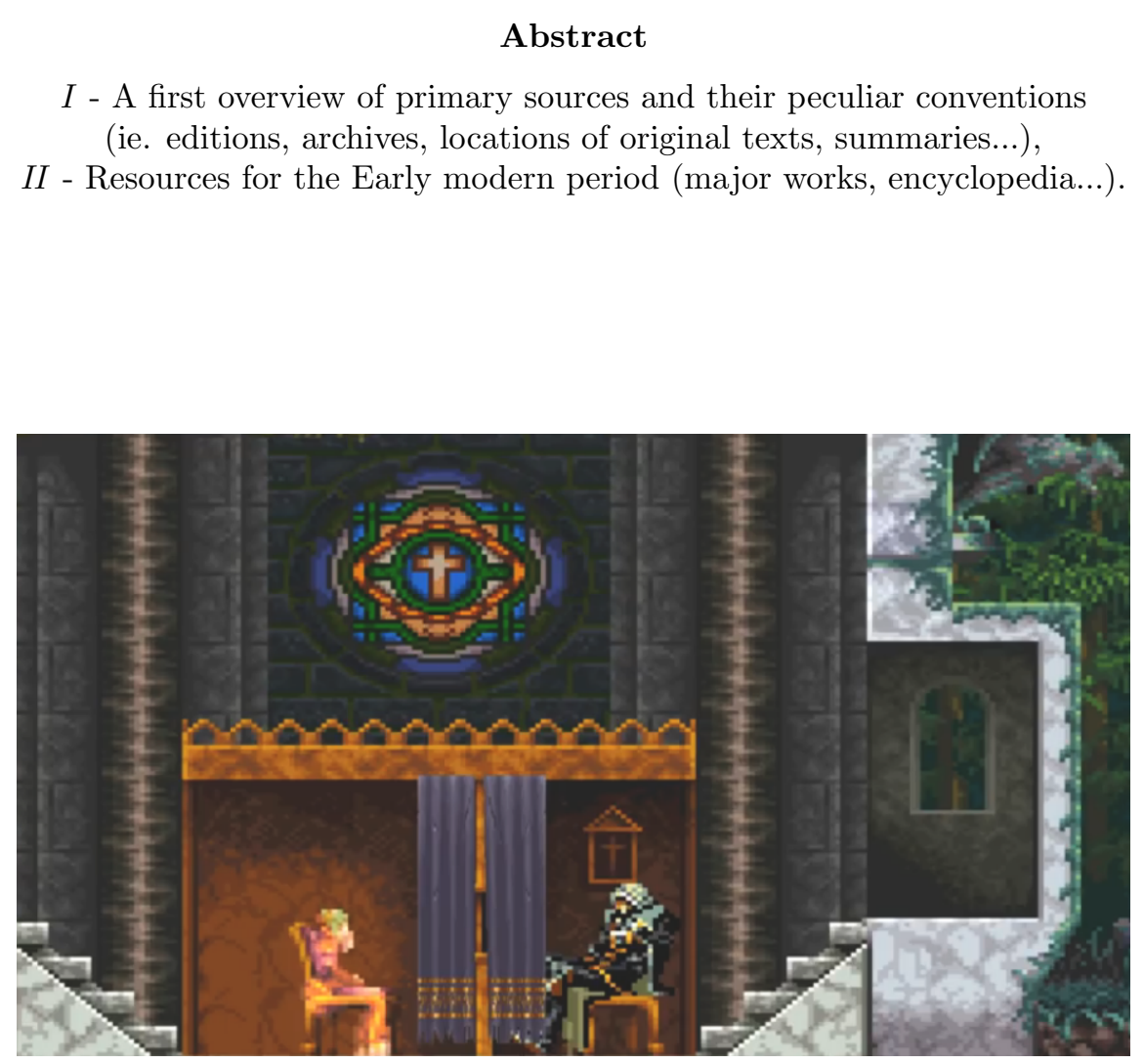


Unless otherwise noted ${ }^{\mathrm{x}}$ all translations were ours. They come principally from older and modern French, and German (forcefully Latin).

\section{Primary sources}

Pascal, Blaise.

- 1640. "Essay sur les coniques". [Early mathematics paper] e.g. Brunschvicg/Boutroux 1923 : c. 260.

- "Advis. Necessaire a ceux"... / 'Notice. Useful to those who will wish to see the Machine for arithmetic, and to use it'. [Description-advertisement]

- (attr.). "Paroles pour un air". [Poetry]

- (to). 1649. Privilege. [Patent for the arithmetic machine]

e.g. Brunschvicg/Boutroux 1925 : 401 ff.; Brunschvicg 1904 : 340 (partial?)

- 1651. [Temp. title: Jacqueline's inheritance].

e.g. Brunschvicg/Boutroux 1925 : 565 ff.

(Another one of those events that highlighted certain qualities existing within Pascal, and that may have contributed to his conversion. NB 1651, death of their father)

- (attr.). c. 1653. Discours sur les Passions de l'Amour / 'Discourse on the passions of Love'.

e.g. Brunschvicg/Boutroux vol $3: 119 \mathrm{ff}$.

(Discussion of attribution divided into 'external', ie. sources/archives, and 'internal' criteria, ie. could Pascal have written such a text : c. 114-15.)

- 1654. ['Memorial' ('amulet')]. 
- Cousin, Victor. 1844. Des Pensees de Pascal. Lib. phil. Ladrange.

(Begins with the Report; Pensees based on the Manuscript in appendix.)

- Faugere, Prosper (ed.). 1844. Pensees... Andrieux.

Vol. 1 : introduction, letters...; Vol. 2 : Pensees.

(In the introduction Faugere credits Cousin of "having made disappear, without replacing it one of the great books"...)

- Brunschvicg, Leon (ed.). 1904. Oeuvres de Blaise Pascal. Pensees. T. 1-3. Hachette.

The 'thematical' edition : here the fragments were organized around themes; also called 'subjective'.

(Not very useful for research, ie. no conclusions regarding order or structure should be made based on this, but possibly the most widely available version, being out of copyright?, so for now it can't be bad practice to provide references.)

- Lafuma, Louis (ed.). 1952. Pensees. 3 vol.. Ed. Luxembourg.

After Cousin the next biggest innovation in the edition of the Pensees : based on Copy 1, rather than the manuscript.

(Vol. 1 : Pensees based on $\mathrm{C}_{1}$; Vol. 2 : notes; Vol. 3, first part : mostly the usual biographies of Pascal...)

Section II : the unnumbered fragments

section III : the fragments not present in $\mathrm{C} 1$ but found elsewhere (e.g. Manuscript). [Newer editions have tried to establish an original ('objective') order but not based on that of the Manuscript, but this time on (two) existing copies, $\left(\mathrm{C}_{1}\right.$ and $\mathrm{C}_{2}$ ), some emphasise one over the other, including Lafuma, and Sellier...] 


Useful for making sense of some of the sources
P-R, or variants thereof : Port-Royal (edition)
B : Brunschvicg or Bossut (depending on period / context)
MsC : Manuscript
[e.g. Lafuma uses RO, "receuil original", for this
(hence whenever a mention of "original lost" appears in his tables,
a star, *, is also found under RO) ]
Archives
Manuscript : 9202
Copy $1: 9203$
Copy 2 : 12449
BN = Bibliotheque Nationale (prev. the "Royal Library") Fr $=$
(Fonds) francais

* Arnauld/Nicole(/Pascal...). Logique de Port-Royal / 'Port-Royal Logic'. (Probably the most underestimated and fascinating text of this century.)

* Filleau de la Chaise(?). Discours sur les Pensees.

Presumed summary of talk given by Pascal about his project for the Pensees. (Dubois / Du Bois ...)

* Pascal, Etienne and Roberval. 1636. ['To Fermat']. [Mathematics paper (a letter)]

e.g. Brunschvicg/Boutroux 1923 : 169 and surrounding.

* Pascal, Jacqueline. 1657. Reglement pour les enfants / 'Rules to serve in the government of children'. 
—. 1655. Letter to Pascal from January 19th. [Temp. title : 'Solitary happiness rather than wordly one']

e.g. Brunschvicg/Boutroux vol $7: 83 \mathrm{ff}$.

* Perier (nee Pascal), Gilberte. Vie de (Blaise) Pascal / 'Life of (Blaise) Pascal'.

* Perier, Etienne. 1670. Preface / 'Preface' to the Pensees.

* Perier, Marguerite. ['Memoir'].

* Racine, Jean. Abrege de l'histoire de Port-Royal / 'Port-Royal, a short history'.

* Diderot / d'Alembert (eds). Encyclopedie. Many vol..

(In particular "arithmetique".)

* Jansen. Augustinus...

* Augustine

(De doctrina Christiana and City of God are referenced in Pensees) 
- Cousin, Victor. 1842. Rapport a l'Academie francaise... / 'Report to the French Academy on the need for a new edition of Pascal's Pensees'. In : Cousin 1844 .

(Critique of the Port-Royal edition from 1669 and the 1779 Bossut edition, until then dominant.)

4-8: Descartes vs. Pascal
9-10: major issues (with the ed. of 'Pensees')
$11-18$ : what sources exist
$18-19$ : structure of the report
20 - First part -
$23:$ what C. understands as being part of P.
$25 \mathrm{ff}:$ critique of Bossut's edition
$47 \mathrm{ff}:$ critique of Port-Royal's edition
$69:$ conclusion/summary
72 - Second part -
$88:$ details the various kinds of P-R alterations
$90-91$ : those "fortunate", "necessary" ones
$92:$ useless corrections
$102:$ really bad ones (additions)
$105:$ really bad ones (suppressions)
$113:$ major revisions
(this should make it easier to start working on this)

- Brunschvicg, Leon and Boutroux, Pierre later Glazier (eds). Various years. Oeuvres de Blaise Pascal... [“... in chronological order ..."]. Many vol.. Hachette. 


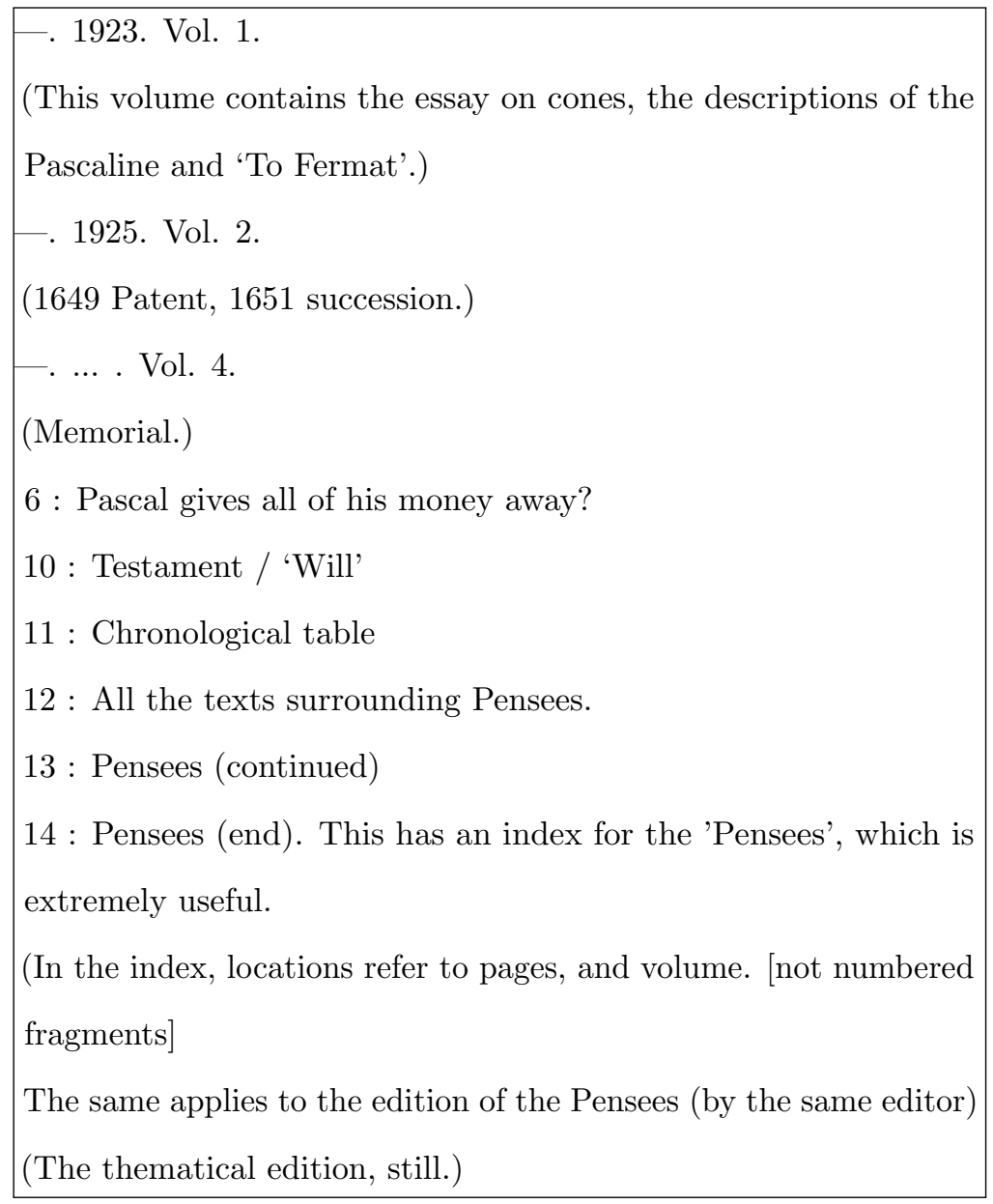

- Faugere (ed.). 1845. Lettres, opuscules et memoires... Vaton.

(452 ff. contains Marguerite's memoir; 353 ff. Jacqueline's 19/01/55 letter)

- (ed. unknown). 1858. Pensees de Pascal... Firmin Didot etc..

(One of many editions containing Gilberte's 'Life of Pascal'.)

- Giraud, Victor (int. and notes). 1922. Discours sur les Pensees... Bossard.

(Contains e.g. "Discours sur les Pensees" among others) 


\section{Bibliography}

- Aries, Philippe. 1962. Centuries of childhood. A social history of family life. Knopf.

- x-. 1975. Western attitudes toward death. From the Middle ages to the present. Marion Boyars.

- Bachelard, Gaston. ['The formation of the scientific mind'].

(Divisions in three periods, 'professorial mind' : preface; salon : ch. 2)

- Bauer, Friedrich. 2009. Historische Notizen zur Informatik. Springer.

(Computer scientist-turned-historian. Spiritual history. (Sociol. important.))

- ${ }^{\times}$Braudel, Fernand. 1985. Civilization and capitalism, 15th-18th century. Vol.

1 : The structures of everyday life. Collins sons and co..

- Bergin (ed.). 2001. The Seventeenth Century. Europe 1598-1795. Oxford University Press.

(This volume contains a chronology at the end, fashioned in the grand style of the history of kings and queens, and battles, and occasionaly only science...)

- Brockliss, Laurence. 2001. "The age of curiosity". In : Bergin.

- Chadwick, Henry. 2001. Augustine. A very short introduction. Oxford.

- Destouches, Louis-Ferdinand. 1999. Semmelweis. Gallimard. [Thesis in medicine]

- Dewald (ed. in chief). Europe 1450 to 1789. Encyclopedia of the Early Modern world. Many volumes. Cambridge.

(Vol. 1 : 'Arnauld Family', 'Atheism' ['Bourgeoisie', 'Census']... 2 : 'Death', etc..)

- Durkheim, Emil. 1884. Cours de philosophie... / 'Philosophy lessons given at Lycee de Sens'.

- Giraud, Victor. 1905. Pascal... ['The Man, The Works, The Influence']. Fontemoing. 
- Hazard, Paul. [1935]. La crise de la conscience europeenne. 1680-1715. Fayard. (If what Paul Hazard wrote of Pascal is true, namely that he had no disciples, then we must also contend that later centuries were full of them...)

- Irwin (ed.). 2002. The Matrix and Philosophy. Open Court.

- Lelut, Francisque. 1846. L'amulette de Pascal / 'Pascal's amulet'.

(Divided into two parts, the first of which has little if anything to do with Pascal being a psychologist's reflections on ideas' origins...)

- Michaut, Gustave. 1902. Les Epoques de la Pensee de Pascal. Fontemoing.

- Munck, Thomas. 2001. "Society". In : Bergin.

- Russell, Bertrand. A History of Western Philosophy.

(Ch. "Augustine", "Reformation", "Descartes", "Nietzsche"...)

- Strowski, Fortunat. 1907; 1908. Pascal et son temps. ['Pascal and his time']. Vol. 2 and 3. Plon.

- Taton, Rene. 1962. "Tableau chronologique sommaire de la vie et des travaux scientifiques de Pascal" Revue d'histoire des sciences 15(3-4) : 191-195.

•- - 1963. "Sur l'invention de la machine arithmétique" Revue d'histoire des sciences 16(2) : 139-160.

- Wiesner-Hanks, Merry. 2013. Early Modern Europe 1450-1789. Cambridge.

- Yeffeth (ed.). 2003. Taking the Red Pill: Science, Philosophy and Religion in The Matrix. Summersdale. 